\title{
Erratum to: Crisis, Identity and Migration in Post-Colonial Southern Africa
}

\author{
Hangwelani Hope Magidimisha, Nene Ernest Khalema, \\ Lovemore Chipungu, Tamuka C. Chirimambowa, \\ and Tinashe Lukas Chimedza
}

\section{Erratum to:}

H.H. Magidimisha et al. (eds.), Crisis, Identity and Migration in Post-Colonial Southern Africa, Advances in African Economic, Social and Political Development,

\section{DOI 10.1007/978-3-319-59235-0}

There is a spelling error in the author name (Innocent Moyo). The name must spell "Inocent" instead of "Innocent" and it has been corrected in Table of Content, About Editors and Authors, Chapter 6, Chapter 10.

\footnotetext{
The updated online versions of these chapters can be found at 